\title{
Young Citizens, ICTs and Learning
}

\author{
A Design for a Study of the Media and Political Activity ${ }^{l}$
}

\author{
TOBIAS OlsSON
}

It is a well-known line of thought that the western democracies are in a state of crisis. The idea of a crisis of democracy can be found in public as well as in scholarly debate. Often varying with political ideology, the perceptions can include various dimensions. Anything from increasing social gaps via problems of integration and xenophobia to decreasing participation in general elections, are therefore - from time to time - subsumed under the idea of a crisis.

Also the Swedish debate on contemporary democracy is inspired by these ideas of a crisis. Not least the Swedish governmental commission into the state of democracy has contributed in making ideas of a crisis of democracy prevalent. The final report of the commission was published in the spring 2000 , and it used the idea of a crisis both as a point of departure and understood it as a problem to be dealt with through the work of the investigation (SOU 2000:1).

There are of course local, Swedish variations to the theme of a crisis. In the Swedish debate a couple of themes have appeared particularly frequently. The decreasing participation in the general elections is one such theme (www.val.se). Another theme is the weakening participation in the established political parties. For instance, it has been stated that if the number of members within political parties keeps decreasing as much as it currently does, the political parties are at risk of becoming deserted by the year of 2013 (Petersson, 2000). Also the decreasing activity within civil society has been mentioned as an indication of a crisis in the Swedish democracy (Petersson m.fl., 1998), though it cannot be excluded that it is a theme that has been inspired by the world encompassing debate on the subject (Putnam, 1995; 2000). A disbelief in and cynicism towards elected officials is another theme that has been brought up in the Swedish debate on the crisis of democracy (Lewin, 1998; Möller, 2000).

A recurrent theme within these debates is the worry about the young people, the citizens of tomorrow. The young voters are strongly represented among the citizens not participating in the general elections (www.val.se). They also show a weaker interest than the grown ups in joining the established political parties, and - furthermore - they show little interest in what is going on within political debates (Ungdomsstyrelsen, 2003). It does not help that the young citizens show a slightly stronger interest in alternative political movements than the grown ups, such as the Animal right's movement, Attac or Amnesty International; the perception that an even bigger crisis of democracy is yet to come is not that easily swept away.

The theme - the young citizens' weakening interest in politics - also inspires this project, but the project does not take the ideas of a crisis for granted, and above all, not the ideas of what constitutes "the political" that seem to inspire several discussions about a crisis of contemporary democracy. The project of course takes the ideas of a crisis seriously, but it approaches the theme differently. First, it does not set out to bring more fuel to the idea of a crisis, which becomes obvious by the project's design - politically active as well as politically uninterested youth are included in the project, which means that the results hardly will be another report of a "crisis". Secondly, the project starts from a slightly different view of politics than the view that inspires the ideas of a crisis, taking a more encompassing view. Thirdly, the project puts specific focus on the media, both the traditional media ${ }^{2}$ and the

Tobias Olsson, Senior Lecturer, Ph. D., Media and Communication Studies, Lund and Växjö University, tobias.olsson@svi.vxu.se 
new ICTs and asks questions about their significance as resources for political interest and engagement.

\section{Research Question}

The research question from which the project departs, and which thus also runs through all its three case studies, is:

What are the traditional media's significance - in general - and the new ICTs' - in particular - for young people in their role and identity as citizens?

Of special interest is the notion of learning: how do young citizens use the traditional media and the new ICTs to learn what they need to know in order to become active citizens?

The research question runs through the three studies of three different groups of young citizens (16-19 years of age): 1) young people that participate and are members in youth organizations affiliated with the established political parties, 2) young people that are members and participate in so called alternative political movements, for instance associations for ethnic minorities and 3) young people that participate in organizations within civil society that lack explicit political aims, for instance football clubs.

The research question can also be expressed in terms of aim and purpose:

Aim: to study the political activity, the media practises and the perceptions of the media in three different groups of young people, groups that show varying degrees of political activity.

Purpose: to discuss the traditional media's - in general - and the new ICTs' - in particular - significance for the creation of civic cultures among young citizens in late modernity.

The project uses qualitative methods, and each group of the three groups of young citizens consists of some 20 respondents, 10 respondents that are recruited in a big city area and 10 that are recruited in a smaller Swedish town and the rural areas surrounding it. The project started in May 2003 and runs for three years.

\section{The Project's Place in the Field of Contemporary Research}

The design of the project and its intellectual interest is best understood as being related to two established tracks in contemporary media studies. On one hand the project is inspired by the research on the media audience and the media use that has been undertaken within cultural theory and in particular its' late modern forms. On the other hand it is inspired by and keeps up a continuous discussion with the research tradition often referred to as political communication. The two traditions of research do not always make up a comfortable combination, thus it is of relevance to reflect upon just 1) how they inspire the project and 2) the limits of each tradition, and how they might complement each other.

\section{Late Modern Cultural Theory and Media Use}

\section{Cultural Theory}

The heading "cultural theory" is of course very overarching and loose. But for the project, the branch of studies within cultural theory that pays specific attention to media use - recently also the use of new ICTs - brings most of the inspiration, which also pin points an important limit to frames of reference (Williams, 1974; Morley \& Silverstone, 1990; Silverstone \& Hirsch, 1992; Moores, 1995; Silverstone, 1994; Mackay \& Gillespie, 1992; Mackay, 1995; Lie \& Sørensen, 1996; Miller \& Slater, 2000; Moores, 2000; Olsson, 2002; Lievrouw \& Livingstone, 2002; Slack \& Macgregor Wise, 2002). ${ }^{3}$

From the study of media use within cultural theory, at least two important thoughts are collected. First, the general view of media and ICTs. Simply put, this view of the media suggests that the media should be looked upon as socially and culturally shaped and that they - once they meet their users are being reshaped once again. Put somewhat differently, this means that the "consequences" of the media - or the notoriously dubious concept "effects" - have to be understood as being dependent upon the uses and perceptions of the technology that are shaped in the interaction between the technology per se and different social and cultural groups of users.

The view of technology within cultural theory insists that the traditional media - just as the new ICTs - are never innocent, or neutral. Rather, they need to be understood as having been shaped by certain purposes (cf Sussman, 1997; Golding, 1998; McChesney, 1999; Garnham, 2000; Lessig, 2001). The cultural perspective also reminds that the technology never quite turns into what it is expected to become. Instead, it is always subject to reshaping and remoulding in its interaction with its users ( $\mathrm{cf}$ Noble, 1984; Mackay et al, 1995). ${ }^{4}$

Another important contribution to the project from cultural theory is the qualitative approach, 
both in terms of data collection and data analysis (Hammersley \& Atkinson, 1995; Silverman, 2000; Olsson, 2002). The project uses methods such as semi-structured interviews, participant observation and focus group interviews; an arsenal of methods that has come to signify the research on media use within cultural theory.

\section{The Late Modern ${ }^{5}$}

The ideas about the late modern - or late modernity can partly be seen as attempts to specify the character of contemporary society. They point to the fact that the world no longer is "modern", but also to the fact that it is neither relevant to use the more challenging concept "post-modern" to describe it (Baudrillard, 1983; Featherstone, 1995; Fornäs, 1995). Late modernity thus signals something else, a more radical modernity, a modernity in which the logic of modernity itself has been pushed to its edge.

But the concepts late modern or late modernity should not be reduced into being only an effort to decide on the species of contemporary society. They are also parts of an intellectual project trying to adapt traditional ideas about culture and society to a changing world. In the adaptive process a couple of themes have become especially salient: questions about globalisation (Bauman, 1998; Tomlinson, 1999), identity (Giddens, 1990), reflexivity (Beck, 1986/1994; Giddens, 1991; Beck et al, 1994; Thompson, 1995) and individualization (Bauman, 1997/1999; 1999/2000).

This is not the context for a discussion of these debates (cf Olsson \& Dahlgren 2003). Instead it is more important to make a short note on what it is in the debates on late modernity that the project takes as points of departure. Two separate but related ideas appear most important: 1) what does late modernity means to the citizenship's social and cultural prerequisites? and 2) identity issues among the late modern citizens.

An important part of the late modern citizen's social and cultural conditions of life (1) is made up of what is usually referred to as individualization. The sociologist Zygmunt Bauman, for example, has stated that late modernity is an era in which market relations have come to colonise and dominate other spheres of life. Thus, Bauman argues that the space for political action has become limited, and that the consumer rather than the citizen is becoming the dominating role for late modern individuals:

The art of re-shaping private problems into public issues is at risk of being forgotten; private matters are defined in such a way that they become hard to agglomerate and thus to condense them into political power (Bauman, 1999: 14-15, my translation from the Swedish translation).

Bauman's idea of individualization also serves as an important point of departure for this project. The fact that the roles of citizen are played out in an environment hostile to such action, makes up an important theoretical frame of reference for the project, which - for instance - means that the politically active young citizens, for analytical reasons, are interpreted as actually conducting deviant behaviour (Goode, 1996).

Late modernity also affects the citizens' identities in several ways. First: the logic of individualization also creates its' subjects. Simply put, this means that the human being to a greater extent than during earlier epochs is being shaped into a consumer rather than into a citizen (cf. Lindqvist, 2001; Mårtensson, 2003). From this point of view individualization does not mean just a decreasing space for acting as a citizen, but also a re-moulding of what once was civic subjects into consumer subjects. Second: processes such as globalization and reflexivity makes problematic the very concept identity, which - arguably - has contributed to making questions of identity a central issue in contemporary social science. From these sprawling debates, at least a couple of important ideas are picked up in this project: The idea that the citizenship also inherits dimensions of identity, an idea that otherwise tends to be neglected in research on the media and citizenship (see below, the part on "Political communication"), also the notion of the human identity as being of constructed nature, and as such subject to a constant moulding and remoulding.

\section{Shortcomings}

Even though ideas stemming from within cultural theory and the thoughts on late modernity inspire this project, there are also problems attached to these ideas that the project has to compensate for in order to make them useful. One such problem is their reluctance to pay specific interest to questions of citizenship and, more generally, political processes.

Contemporary cultural theory has not paid too much attention to questions of citizenship. The tradition of course brings important reflections on the political, notably when it comes to its various dimensions of gender (cf. van Zoonen, 1994; Hermes, 
1995) and ethnicity (cf. Gillespie, 1995; Lull, 2000). But nonetheless it has been preoccupied with question of ideological - or discursive - resistance and opposition against dominating structures of power. The citizen as a social category has been pretty much absent in this context until quite recently (Stevenson, 2001), when the cultural dimensions of the citizenship reached the research agenda.

What is missing is an interest in civic practises that engage individual citizens' in their role as citizens. That is an area which cultural theory, so far, to a great extent has left to other research traditions to handle. What in this context appears to be a specific shortcoming is the lack of interest in the citizens' information and communication practises; their uses and perceptions of the media in their role as citizens, and this project intends to address these. ${ }^{6}$

The specific ideas on late modernity also carry with them features that make up problems to this project. First of all, like cultural theorists in general, they are not paying any specific interest to citizens or the ideas on citizenship, even though they are suggestive when it comes to understanding the contemporary opportunities and limits of the role/identity as citizen (Bauman, 1997/1999; Beck \& BeckGernsheim, 2002). ${ }^{7}$

Instead, specific attention has been paid to the role and - also - the identity as consumer. Not least within Swedish research has the ideas on late modernity become intimately connected to studies on consumption in general and media consumption in particular (cf. Reimer, 1994; Jansson, 2001; Becker et al, 2002). In order to make the ideas on late modernity useful in this project, they need to be reshaped in order to pay specific attention to the citizen rather than to the consumer - without necessarily radically polarizing the two categories - and that is not only a change of concepts. It is also a matter of looking at media use from another angle and to pose new and partly different questions to it.

\section{Political Communication}

The second research tradition, in order of appearance, to inspire this project is political communication (Asp, 1986; Blumler \& Gurevitch, 1995; Negrine, 1994; 1996; Watts, 1997; Wheeler, 1997; Johansson, 1998; Norris, 2000; McNair, 2003). Here, research on the communicative interaction between the formal actors within political communication - political institutions/actors, the media and citizens - is put into focus. Election campaigns, political journalism, public information and the perception of politicians among voters are a few of the research themes that frequently appear within political communication.

Jay G Blumler and Michael Gurevitch, two leading scholars, describe political communication like this:

Expressed somewhat differently, if we look at a political communication system, what we see is two sets of institutions - political and media organizations - which are involved in the course of message preparation in much 'horizontal' interaction with each other, while on the 'vertical' axis, they are separately and jointly engaged in disseminating and processing information and ideas to and from the mass citizenry (Blumler \& Gurevtich, 1977: 271).

\begin{abstract}
Much of our own past work [...] was predicated on the view that an understanding of the processes of political communication required a systemic perspective, i.e. one in which the different components of the system - media institutions and professionals; political institutions, parties and political advocates; audience members placed at the receiving end of the output produced by these institutions; and the surrounding sociopolitical environment - interact and impact upon each other, such that change in one triggers adaptive changes in the rest of the system (Blumler \& Gurevitch, 2000: 157).
\end{abstract}

Blumler and Gurevitch describe political communication as a system with three main components: political institutions, media institutions and audiences. Furthermore, they explain that political communication arises in the interaction between the system's components.

The short description makes a couple of strengths of the research tradition obvious. One such strength is its intense focus on political issues in general and civic issues in particular. Another strength is the way the tradition, being much untouched by current trends within research, carries on its focus on the interaction between the three components of the so called system: political institutions/the media/citizens.

From this research tradition the project picks up a couple of ideas. First, it is inspired by the general interest in questions dealing with politics and democracy, and especially questions dealing with issues of citizenship - in general - and the media's contribution to citizenship in particular. But the tradition also carries with it a couple of characteristic features that become troublesome for this project and that have to be modified in order to work out well. 
The first problem is of methodological kind: the research tradition political communication is dominated by statistical methods and analysis, and even though this is not the place for a thorough discussion on methodology, it has to be mentioned that the project uses a completely different approach. The project approaches the area with methods such as semi-structured interviews, participant observation and focus group interviews rather than surveys or factor and regression analysis. This of course also brings a completely different analytical approach.

Another such problematic feature of the research tradition, that has to be revised in order to work out well within this project, is its limited view of politics. Probably it is not any deliberate choice, but at the end of the day, most studies within political communication tend to work from the assumption that the "political" is being played out in the interaction between the three parts in political communication: the media, political actors/institutions and the citizens. At first this might seem to be quite an encompassing view, but not in practice. A survey of the articles within the research field's dominating periodical Political communication makes that obvious: among the articles we find for instance a special issue on the American election of president (Bimber, 2002), an article on knowledge gaps in the same election (Holbrook, 2002), an article on the citizens' perceptions on the fairness in the news media's reporting (Earl et al, 2001), a text on male and female political candidates presentation of self on the internet (Niven \& Zilber, 2001) and another article on gaps in knowledge and varying participation in political life due to the various uses of news media and - finally - a text on the classical theme on whether the news media can impact the turn out of a political election (Shaw, 1999).

The research on the field is thus heavily focused on the interaction between the formal actors in politics. As such, it also tends to leave out other areas that potentially could be interesting from a political point of view, for instance civic activities within civil society (cf. Downey \& Fenton, 2003) and civic participation in alternative public spheres (cf. Papacharissi, 2003).

The limited view of the political within the field political communication becomes problematic to this project. First because the project in two cases out of three chooses to work with groups of young citizens that can't easily be described as "political" according to the view put forward by the research within political communication. Second, because the project intents to approach the reality with a more open minded view of what constitutes the political.
Another characteristic feature of the research tradition, that makes up a problem for the intentions of this project, is its tendency to focus on the citizens' opinions and knowledge. Of course, these are important areas of research, but for this project such a focus becomes problematic. The focus on opinions and knowledge puts too much emphasis on the informational aspect of citizenship, while it fails to acknowledge other aspects of the citizenship. With inspiration from contemporary cultural theory, also other aspects of the citizenship turn out to be of great interest for research.

\section{Theoretical Framework: What Becomes of the Connection Between Cultural Theory and Political Communication?}

We cannot claim full originality in trying to incorporate elements from the two different traditions, and in regard to theme of the project we are certainly inspired by the works of for instance David Buckingham (2000). In the direction we take, however, the project interconnects the two traditions by help from Peter Dahlgren's concept civic culture. Compared to cultural theory and the ideas on late modernity, Dahlgren's concept adds a more obvious focus on the citizen, the citizenship and - especially - its subjective dimensions (i.e. aspects of identity). Compared to political communication, Dahlgren's ideas add an extension of the political and bring a more complex view of the citizen; new dimensions appear to be of relevance to the citizenship (cf. Dahlgren, 2000).

In more detailed terms, Peter Dahlgren's notion of civic culture inherits six intimately connected but analytically separated dimensions (Dahlgren, 2003): 1) knowledge, 2) values, 3) affinity, 4) practices, especially discussion and 5) identity.

In this case, the concept knowledge refers to the fact that democracy in order to function needs citizens that are able to access and use reliable descriptions of reality. Of great importance is also that the citizens have good prerequisites to follow up on current debates. Also, another set of knowledge and competences are of importance; communicative competencies to participate in public life. Here we also find an interesting component of learning (Säljö, 2000; Graber, 2001) to pay attention to: through what media and in what ways do the young citizens learn what they need to know to act as citizens?

The concept values refers to a loyalty towards the values and procedures that the democracy depend upon. Without virtues such as tolerance and a will- 
ingness to attend to democratic principals in everyday life, democracy as a form of governance will not survive, Dahlgren states. The citizens' efforts to create democracy must be manifested in everyday life, citizens have to maintain and cultivate democracy as mechanism for the solving of problems.

Affinity refers to the citizen's feelings of belonging to and being part of various kinds of collectivities. It of course refers to the citizens' feeling of belonging to and being part of society at large, but also to the citizens' senses of belonging to various kinds of smaller associations within civil society. The sense of belonging to and feeling of being part of are important ingredients in the creation of good democratic prerequisites. Citizens who do not have a sense of belonging to, and are not invited to have it, have problems in contributing to the reproduction of democratic values.

There are also practices to be considered, practices such as conducting meetings or handling a debate according to democratic principles. But the civic culture also needs: "[...] bigger, more integrating practises on a collective level that actively brings heterogeneous people into a common, democratic ideal" (Dahlgren \& Olsson, 2003). Election campaigns could be one such example that contributes in consolidating democracy as an ideal. Discussion is perhaps the most important practise of all within civic culture. This means that there has to be places, rooms, contexts and social norms that promote the "talking" as a way of solving problems and dealing with disagreements. The discussions are also contributing in creating and re-creating the democratic values that the civic culture relies on.

Last but not least, the civic culture also contents a dimension of identity, that people are able to think of themselves as citizens and cultivate an image of themselves as citizens (cf. Mouffe 1992; Clarke, 1996; Preston, 1997; Isin and Wood, 1999; Ellison, 2000). Of course, this does not mean that people think of themselves as "citizens" - probably no one who is not already very familiar with academic de-

\section{Notes}

1. This project is supported for three years by the Swedish foundation KK-stiftelsen (Learn-IT, KK-foundation). This article is based on encompassing discussions with Peter Dahlgren, head of the project, and Malin Hjorth, who is conducting parts of the field research. bates on the issue would present oneself in such a manner. Instead, what the concept aims at catching is an image among people of themselves as being at least - potential participants in political life, that they have an elementary sense of being part of a bigger community.

Since the project pays special attention to the media in general and to the new ICTs in particular, it looks upon the media and ICTs to be important factors for all of the dimensions of civic culture. The traditional media - i.e. the press, radio and $\mathrm{TV}-$ and not least the new ICTs are looked upon as potentially bringing positive contributions to the working civic culture, but also to its opposite. If used in the right way, the media can be resources for people in their role and identity as citizens.

It is thus a fundamental assumption for the project that there are interesting dimensions in terms of civic culture to be found in the young citizens use and perception of the media. The project's empirical studies aim at describing, come to grips with and critically discuss these dimensions.

\section{Carrying Through}

The first in order of three empirical studies has already started (October 2003) and puts focus on young citizens who are organised in youth organisations affiliated with traditional political parties. A working paper from that study will be presented during summer 2004. Thereafter follows another case study of young people that are involved in alternative political movements such as ethnic groups, Attac or the Swedish neo-liberal organisation Frihetsfronten. A working paper from that study will be presented in the summer 2005. The third case study will be a study of young citizens who are not involved in any such organisation that we usually and traditionally describe as political, for instance young people in sports clubs. After the third case study a final report from the project will be presented during summer 2006.
2. The concept traditional media refers to - basically all media except for computer based media. ICTs, information and communication technologies, refers to computer based media.

3. We can mention in passing that while cultural studies certainly encompasses some, but not all of this terrain, we do not use that category here. The field of cultural studies raises too many issues about its' definitions 
and boundaries which would require a long discussion, too long to be fruitful for our purposes here.

4. The important points made by the perspectives within cultural theory are better understood in the light of other perspectives on technology. For example, the notoriously criticised view of technological determinism perceives the media to be the dominating shaper of social and cultural circumstances (cf McLuhan, 1962; 1964; Negroponte, 1995; Levinson, 1997; 1999). Against such a perspective on the media, contemporary cultural theory emphasises that the media have to be understood as being socially and culturally shaped.

5. The ideas of late modernity of course have evident connection to cultural theory, not least due to the fact that they quite often stem from ideas within cultural theory. Nevertheless, the ideas about the late modern cannot be reduced to just another branch of cultural theory. A quick look into the literature in this area reveals that much of the intellectual heritage on this issue comes from more traditional sociology.

6. This shortcoming has been noted elsewhere in the literature. The media researcher Denis McQuail touches upon it when he argues that cultural studiesresearchers need to do a better job addressing policy issues (1997). Similar ideas are presented by the sociologist Jim McGuigan (1992). Also, the concept Social demand, launched by the Canadian media scholar Mark Raboy (Raboy et al, 2003), is at least partly an effort to compensate for this shortcoming within research (se also Olsson et al, 2003).

7. Of course there are exceptions. One such exception is the Swedish media researcher Bo Reimer who has theorized the late modern (or post modern) citizenship in the book Politics in postmodernity (1999).

\section{References}

Asp, K. (1986) Mäktiga massmedier: Studier i politisk opinionsbildning. Stockholm: Akademilitteratur.

Baudrillard, J. (1983) Simulations. New York: Semiotext(s).

Bauman, Z. (1997/1999) Vi vantrivs $i$ det postmoderna. Göteborg: Daidalos.

Bauman, Z. (1998) Globalization: The Human Consequences. London: Polity.

Bauman, Z. (1999) På spaning efter politiken. Göteborg: Daidalos.

Beck, U. (1986/2000) Risksamhället: på väg mot en annan modernitet. Göteborg: Daidalos.

Beck, U. \& E. Beck-Gernsheim (2002) Individualization: Institutionalized Individualism and its Social and Political Consequences. London: Sage.

Beck, U., A. Giddens \& S. Lash (1994) Reflexive Modernization: Politics, Tradition and Aesthetics in the Modern Social Order. Oxford: Polity.

Becker, K., E. Bjurström, J. Fornäs \& H. Ganetz eds. (2002) Medier och människor i konsumtionsrummet. Nora: Nya Doxa.
Bimber, B. (2002) 'Political Communication in the 2000 Election: Guest Editor's note'. In Political Communication. Vol. 19 (1). Taylor \& Francis.

Blumler, J.G. \& M. Gurevitch (1977) 'Linkages Between the Mass Media and Politics'. In J. Curran, M. Gurevitch \& J. Woollacott eds. Mass Communication and Society. London: Edward Arnold.

Blumler, J.G. \& M. Gurevitch (1995) The Crisis of Public Communication. London and New York: Routledge.

Blumler, J. G. \& M. Gurevitch (2000) 'Rethinking the Study of Political Communication'. In Curran, J. \& Gurevitch, M. (eds.) Mass Media and Society. Third edition. London: Arnold.

Buckingham, D. (2000) The Making of Citizens: Young People, News and Politics. London: Routledge.

Clarke, P.B. (1996) Deep Citizenship. London: Pluto.

Dahlgren, P. (2000) 'Media, Citizenship and Civic Culture'. I J. Curran \& M. Gurevitch eds. Mass Media and Society. Third edition. London: Arnold.

Dahlgren, P. (2003) 'Reconfiguring Civic Culture in the New Media Milieu'. In J. Corner \& D. Pels eds. Media and the Restyling of Politics. London: Sage.

Dahlgren, P \& T. Olsson (2003) 'Unga medborgare, IKT och lärande - ett idédokument'. Article presented at the 16 th Nordic conference in media research, august 2003. Kristiansand, Norway.

Downey, J \& N. Fenton (2003) 'New Media, Counter Publicity and the Public Sphere'. In New Media and Society. Vol. 5 (2). London: Sage.

Earl, S., S. Rhine \& R. Flickinger (2001) 'Assessing Americans' Opinions about the News Media's Fairness in 1996 and 1998'. In Political Communication. Vol. 18 (2). Taylor \& Francis.

Ellison, Nick (2000) 'Civic-Subjects or Civic-Agents? The Structure-Agency Debate in Late Modern Perspective'. In Theory, Culture \& Society 17, 148156.

Featherstone, M. (1995) Undoing Culture: Globalization, Postmodernism and Identity. London: Sage.

Fornäs, J. (1995) Cultural Theory and Late Modernity. London: Sage.

Garnham, N. (2000) Emancipation, the Media and Modernity: Arguments About the Media and Social Theory. Oxford: Oxford University Press.

Gibbins, J. \& B. Reimer (1999) The Politics of Postmodernity: An Introduction to Contemporary Politics and Culture. London: Sage.

Giddens, A. (1990) The Consequences of Modernity. Cambridge: Polity Press.

Giddens, A. (1991) Modernity and Self-Identity: Self and Society in the Late Modern Age. Stanford: Stanford University Press.

Gillespie, M. (1995) Television, Ethnicity and Cultural Change. London: Routledge.

Golding, P. (1998) 'Global village or cultural pillage'. In R. McChesney, E. Wood-Meiksins \& J. FosterBellamy eds. Capitalism and the Information Age: The Political Economy of the Global Communication Revolution. New York: Monthly Review Press. 
Graber, D. (2001) 'Adapting Political News to the Needs of Twenty-first Century Americans'. In L. Bennett \& R. Entman, eds. Mediated Politics: Communication in the Future of Democracy. New York: Cambridge University Press.

Goode, E. (1996) Social Deviance. Boston: Allyn and Bacon.

Hammersley, M. \& P. Atkinson (1995) Ethnography: Principles in Practise. Second edition. London: Routledge.

Hermes, J. (1995) Reading Women's Magazines. Cambridge: Polity.

Holbrook, T. (2002) 'Presidental Campaigns and the knowledge gap'. In Political Communication. Vol. 19 (4). Taylor \& Francis.

Islin, E. \& P. Wood (1999) Citizenship and Identity. London: Sage.

Jansson, A. (2001) Image Culture: Media, Consumption and Everyday Life in Reflexive Modernity. Diss. Göteborg: JMG, Göteborgs universitet.

Johansson, B. (1998) Nyheter mitt ibland oss: kommunala nyheter, personlig erfarenhet och lokal opinionsbildning. Diss. Göteborg: JMG, Göteborgs universitet.

Lessig, L. (2001) The Future of Ideas: The Fate of Commons in a Connected World. New York: Random House.

Levinson, P. (1997) The Soft Edge: A Natural History and Future of the Information Revolution. New York: Routledge.

Levinson, P. (1999) Digital McLuhan: A Guide to the Information Millennium. New York: Routledge.

Lewin, L. (1998) "Bråka inte": om vår tids demokratisyn. Stockholm: SNS förlag.

Lie, M. \& K. Sørensen eds. (1996) Making Technology Our Own: Domesticating Technology Into Everyday Life. Oslo; Stockholm; Köpenhamn; Oxford and Boston: Scandinavian University Press.

Lievrouw, L. \& S. Livingstone (2002) 'Introduction: The Social Shaping and Consequences of ICT's'. In L. Lievrouw \& S. Livingstone eds. The Handbook of New Media. London: Sage.

Lindquist, M. (2001) Is i magen: om ekonomins kolonisering av vardagen. Stockholm: Natur \& kultur.

Lull, J. (2000) Media, Communication and Culture: A Global Approach. Second edition. Oxford: Polity.

Mackay, H. (1995) 'Theorising the IT/society relationship'. In N. Heap, R. Thomas, G. Einon, R. Mason \& H. Mackay eds. Information Technology and Society: A Reader. London: Sage.

Mackay, H., N. Heap, R. Thomas, G. Einon, \& R. Mason (1995) eds. Information Technology and Society: A Reader. London: Sage.

Mackay, H. \& G. Gillespie (1992) 'Extending the social shaping of technology: ideology and appropriation'. In Social Studies of Science. Vol. 22 (4).

McChesney, R. (1999) Rich Media, Poor Democracy: Communication Politics in Dubious Times. Urbana and Chicago: University of Illinois Press.

McGuigan, J. (1992) Cultural Populism. London: Routledge.
McLuhan, M. (1962/1969) Gutenberggalaxen: den typografiska människans uppkomst. Stockholm: Bokförlaget Pan/Norstedts.

McLuhan, M. (1964/1999) Media: människans utbyggnader. Second edition. Stockholm: Norstedts.

McNair, B. (2003) An Introduction to Political Communication. Third edition. London: Routledge.

McQuail, D. (1997) 'Policy help wanted: Willing and Able Media Culturalists Please Apply'. I M. Ferguson \& P. Golding eds. Cultural Studies in Question. London. Sage.

Miller, D. \& D. Slater (2000) The Internet: An Ethnographic Approach. Oxford and New York: Berg.

Moorse, S. (1995) Interpreting Audiences: The Ethnography of Media Consumption. London: Sage.

Moorse, S. (2000) Media and Everyday Life in Modern Society. Edingburgh: Edingburgh University Press.

Morley, D. \& R. Silverstone (1990) 'Domestic Communication - Technology and Meaning'. In Media, Culture and Society. Vol. 12 (1). London: Sage.

Mouffe, C. (ed.) (1992) Dimensions of Radical Democracy: Pluralism, Citizenship, Community. London and New York: Verso.

Mårtensson, B. (2003) Den televiserade ekonomin: Nyheter om statsbudgeten 1980-1998. Diss. Stockholm: JMK, Stockholms universitet.

Möller, T. (2000) Politikens meningslöshet: om misstro cynism och utanförskap. Malmö: Liber.

Negrine, R. (1994) Politics and the Mass Media in Great Britain. Second edition. London: Routledge.

Negrine, R. (1996) The Communication of Politics. London: Sage.

Negroponte, N. (1995) Leva digitalt: om datorer, CD-rom and Internet - för de redan frälsta och oss andra oroliga. Stockholm: Bonnier.

Niven, D. \& J. Zilber (2001) 'Do Women and Men in Congress Cultivate Different Images: Evidence from Congressional Web Sites'. In Political Communication. Vol. 18 (4). Taylor \& Francis.

Noble, D. (1984) Forces of Production. New York: Alfred A. Knopf.

Norris, P. (2000) A Virtuous Circle: Political Communication in Postindustrial Society. Cambridge: Cambridge University Press.

Olsson, T. (2002) Mycket väsen om ingenting: hur datorn och internet undgår att formas till medborgarens tekniker. Diss. AUU: Uppsala Studies in Media and Communication. Uppsala: Uppsala University Library.

Olsson, T., H. Sandström \& P. Dahlgren (2003) 'An Information Society for everyone?'. In Gazette. Vol. 65 (45). London: Sage.

Olsson, Tobias (2004) 'Oundgängliga resurser: Om medier, IKT och lärande bland partipolitiskt aktiva ungdomar', Lund: Media and Communication Studies, Lund University.

Papacharissi, Z. (2003) 'The Virtual Sphere: The internet as a public sphere'. In New Media and Society. Vol. 4 (1). London: Sage. 
Petersson, O., J. Hermansson, M. Micheletti, L. Teorell \& A. Westholm (1998) Demokrati och medborgarskap. Stockholm: SNS förlag.

Petersson, O. (2000) Demokrati utan partier? Stockholm: SNS förlag.

Preston, P.W. (1997) Political/Cultural identity: Citizens and Nations in a Global Era. London: Sage.

Putnam, R. (1995) 'Bowling Alone: America's Declining Social Capital'. In Journal of Democracy. Vol 6 (1).

Putnam, R. (2000) Bowling Alone: The Collapse and Revival of American Community. New York: Simon and Schuster.

Raboy, M., S. Prolux \& P. Dahlgren (2003) 'The dilemma of social demand: Shaping media policy in new civic contexts'. In Raboy, M., S. Prolux \& P. Dahlgren eds. Gazette: The International Journal for Communication Studies. Vol. 65(4-5). Special Issue on: Media Policy and Social Demand: A Transnational Perspective. London: Sage.

Reimer, B. (1994) The Most Common of Practices. Diss. Stockholm: Almqvist \& Wiksell International.

Shaw, D. (1999) 'The Impact of News Media Favourability and Candidate Events I Presidential Campaigns'. In Political Communication. Vol. 16 (2). Taylor \& Francis.

Silverman, D. (2000) Doing Qualitative Research: A Practical Handbook. London: Sage.

Silverstone, R. (1994) Television and Everyday Life. London and New York: Routledge.
Silverstone, R. \& E. Hirsch (ed.) (1992) Consuming Technologies: Media and Information in Domestic Spaces. London: Routledge.

Slack Daryl, J. \& J. Macgregor Wise (2002) ‘Cultural Studies and Technology'. In L. Lievrouw \& S. Livingstone eds. The Handbook of New Media. London: Sage.

SOU 2000:1 En uthållig demokrati! Politik för folkstyrelse på 2000-talet. Demokratiutredningen. Stockholm: Fritzes offentliga publkationer.

Stevenson. N. (ed.) (2001) Culture and Citizenship. London: Sage.

Sussman, G. (1997) Communication, Technology and Politics in the Information Age. London: Sage.

Säljö, R. (2000) Lärande i praktiken: Ett sociokulturellt perspektiv. Stockholm: Prisma.

Thompson, J.B. (1995) The Media and Modernity: A Social Theory of the Media. Cambridge: Polity Press.

Tomlinson, J. (1999) Globalization and Culture. London: Polity Press.

Ungdomsstyrelsen (2003) De kallar oss unga: Ungdomsstyrelsens attityd-and värderingsstudie 2003. Stockholm: Ungdomsstyrelsen.

Watts, D. (1997) Political Communication Today. Manchester and New York: Manchester University Press.

Wheeler, M. (1997) Politics and the Mass Media. Oxford and Cambridge, Massachusetts: Blackwell Publishers.

Williams, R. (1974) Television: Technology and Cultural Form. London: Fontana/Collin.

van Zoonen, L. (1994) Feminist Media Studies. London: Sage. 